\title{
Imagine There are No Possessions: Legal and Moral Basis of the Common Heritage Principle in Space Law
}

\author{
GBENGA ODUNTAN*
}

\begin{abstract}
The article examines the legal validity, import and relevance of the concept of 'common heritage of mankind' in relation to outer space territories. The term common heritage of mankind lends itself to a myriad of possible interpretations. Consequently there is a situation where both proponents as well as adversaries of commercial space activities use the term to advance their standpoints. The push by certain states and their private business institutions to begin exploitation of outer space resources for commercial purposes has become more forceful in the dawn of the twenty first century. It becomes imperative to ascertain the legality of appropriation of outer space resources within the context of the overriding principles that outer space is the common heritage of mankind and the province of mankind. The article, therefore, traces the development of the concept of common spaces in international law and draws upon analogies found in parallel regimes of common ownership over other international spaces such as the deep sea bed and Antarctica. The merits and demerits of the existing interpretations of the CHM principle are considered and the author argues that there are sufficient legal, jurisprudential and indeed moral imperatives to adopt the restrictive view that outer space and celestial bodies cannot as of yet be appropriated for profit motives by both states and private bodies. The author also argues in favour of a moratorium over commercial exploitation until an international regime of exploitation is developed taking into account the interests of all mankind and the reality of private commercial operations in outer space.
\end{abstract}

Two things fill my mind with ever-increasing wonder and awe the more often and the more intensely the reflection wells on them: the starry heavens above me and the moral law within me.

Immanuel Kant (1724-1804)

Critique of Pure Reason

\section{INTRODUCTION}

This article examines the legal validity, import and relevance of the concept of 'common heritage of mankind' in relation to outer space territories and in terms of its development in international law. In view of the restiveness of the technologically advanced states to embark on large-scale exploitation of outer space resources the article argues for the development of a progressive utilisation regime for outer space based resources based upon equitable considerations and taking into account the needs of developing countries. Positive examples found under the existing regime of jurisdiction over the high seabed and Antarctica are reviewed and the problematic features of these international regimes are identified in order to highlight the pathways that must be avoided in the development of the utilisation of outer space resources in space law. The argument in favour of recognition of a de facto moratorium on mining of the resources based on celestial bodies is made and the jurisprudential basis for the common ownership regime established in space law is explored. 
The term common heritage of mankind ${ }^{1}$ is one that manages to appear both commonsensical and obscure at the same time. In reality it lends itself to a myriad of possible interpretations. Consequently there is a situation where both proponents as well as adversaries of commercial space activities use the term to advance their standpoints. ${ }^{2}$ Analogies of this principle can be found in the legal regime governing virtually all the common spaces. Therefore, it is correct to note that "the common heritage principle has its main impact with respect to the establishment of an international administration for areas open to the use of all states (international commons)". ${ }^{3}$ Impetuses for the extension of this principle into outer space would, however, appear to have come from analogies presented in the law of the sea. Though some writers find traces of the contemporary idea of the CHM in the thinking of Francisco de Vitoria ${ }^{4}$ and even earlier St. Thomas Aquinas, ${ }^{5}$ the more popular opinion is that the CHM principle may have been introduced to the law of the sea as a result of a speech made by Ambassador Parado of Malta to the United Nations General Assembly (UNGA) in which he asserted that the future of the resources of the high seas is best secured if it is recognised as the 'common heritage of mankind'. ${ }^{6}$

The principle consequently received recognition in the UN Declaration of Principles Governing the Seabed and the Ocean Floor, and the Subsoil Thereof, Beyond the Limits of National Jurisdiction. ${ }^{7}$ By the time of the completion of the Third United Nations Convention on the Law of the Sea (UNCLOS III) in 1982, it was incorporated in Article 136 of the Law of the Sea Convention that: "the Area and its resources are the common heritage of Mankind". ${ }^{8}$ However, it must be admitted that even in the law of the sea the exact legal effect of this principle is subject to much debate.

\footnotetext{
* Ph.D (Law), MA, LLB (hons) BL (hons) BA (hons); Lecturer in Law, Canterbury Christ Church University College, Canterbury North Holmes Road, Canterbury, Kent CT1 1QU, England; Sessional Lecturer in International law, Constitutional and Administrative Law -Kent Law School, University of Kent at Canterbury; Legal Adviser to the Nigerian Government and Member, United NationsNigerian/Cameroon Mixed Sub-Commission on the Demarcation of the Boundary between Nigeria and Cameroon. This article is based on central aspects of the author's Ph.D. thesis titled Sovereignty \& Jurisdiction in the Airspace \& Outer Space: Legal Criteria for Spatial Delimitation, submitted at the University of Kent (2002). Many thanks to Professor Nicholas Grief, Head of the School of Finance and Law Bournemouth University, U.K. for his helpful comments and ideas during the completion of this article.

This article is based on central aspects of the author's Ph.D. thesis titled Sovereignty \& Jurisdiction in the Airspace \& Outer Space: Legal Criteria for Spatial Delimitation, submitted at the University of Kent (2002).

${ }^{1}$ To be referred to as the CHM Principle.

2 Traa-Engelman, Commercial Utilization of Outer Space: Law and Practice (London, Martinus Nijhoff Publishers, 1993) p. 27.

${ }^{3}$ Rudiger Wolfrum, 'Common Heritage of Mankind', in Rudolf Bernhardt, Max Planck Institute for Comparative Law, Encyclopedia of Public International Law, (Netherlands, Elsevier Science Publishing Company 1989) p. 68.

${ }^{4}$ Sylvia Maureen Williams, 'The Law of Outer Space and Natural Resources', ICLQ 36 (1987) p. 144.

${ }^{5} \mathrm{Ibid}$; see also. Juan A. Travieso, 'El Patrimonio Comun de la Humanidad en el Nuevo Orden International', Vol. 2 Revista del Colegio de Abogados de Buernos Aires (1981).

${ }^{6}$ UNGA Official Records, 22nd Session, Agenda Item 92 (2), Doc. A/6695, 18 August 1967. Article 1 states that: "The sea-bed and ocean floor, and the subsoil thereof, beyond the limits of national jurisdiction (hereinafter referred to as the area), as well as the resources of the area, are the common heritage of mankind".

${ }^{7}$ Reprinted in International Legal Materials, 220 (1971) Article 1.

${ }^{8}$ UNCLOS III ILM 1245 (1982).
} 
In relation to Space Law the CHM principle continues to be a subject of intense controversy pitting two forces against each other. As have been pointed out the divide is between the developing states and the developed space faring states. Most of the former are presently incapable of directly reaping the benefits of space exploration, and most of the latter are pushing aggressively for a favourable regime towards the commercialisation of space activities including extensive mining and appropriation rights. Indeed it is right to say that the concept of the Common Heritage of Mankind and its application still keeps the world community divided. ${ }^{9}$ Opponents of the concept have ceaselessly attacked its legal validity from the time it was introduced in the law of the sea for predominantly the same reasons that it is today contested in relation to the law governing outer space activities. The chief reason is the incompatibility of the concept with unbridled capitalist exploitation of minerals and resources for private ends in a resource rich zone. That is those states that possess the means to exploit resources in remote places do not see any reason why the spoils should be shared with other states that do not.

Many jurists predominantly of western inclination have criticised any possible suggestion that the phrase expresses a legal concept. This is a very clever approach because once the legal validity in concrete terms has been successfully undermined there exists no need to respect any restrictions on the exercise of property rights. A member of this school of thought argues forcefully but not convincingly that:

One caution lawyers, diplomats and statesmen should observe is to avoid trying to treat layman's language as if it were formulated in terms of technical legal concepts...on the other hand, the phrase, common heritage of mankind, a layman's formula if ever there was one should be given the greatest respect, while it should not, indeed cannot be viewed as a prescription, it can be accepted as a kind of policy hortatory message, a kind of policy directive... ${ }^{10}$

In similar terms Gorove insists that;

"common heritage of mankind no matter how well motivated, in a legally binding document carries no clear judicial connotation but belongs to the realm of politics, philosophy or morality and not law". 11

It, however, appears that on the face of it there is nothing really confusing about the CHM principle. It can also be doubted that the view would ever be popular that outer space and the celestial bodies therein should be appropriated as national territory. The

\footnotetext{
${ }^{9}$ Engelman op. cit., p.52. See also K. Gorove and E Kamenetskaya, "Tensions in the Development of the Law of Outer Space in Beyond Confrontation: International Law for the Post-Cold War Era (Boulder: Westview Press, 1995) passim; Gbenga Oduntan, 'The Generational-Technological Gap in Air and Space Law--a Commentary', Journal of Space Law, 29 (2003) pp. 185-186, 200-204.

${ }^{10}$ L. Goldie, 'A General International Law Doctrine for Seabed Regimes', Int'l Lawyer, 7 (1973) pp. $796,819$.

${ }^{11}$ Gorove, 'The Concept of Common Heritage of Mankind a Political, Moral or Legal Innovation', Vol. 9 San Diego, (1996). For further positions stating the alleged indeterminacy of the CHM principle see also Williams, op. cit., p. 144 and Joynes, 'Legal Implications of the Common Heritage of Mankind', ICLQ, 35 (1986) p. 190.
} 
real heart of the dispute is whether or not the CHM principle will be able to accommodate an international regime based on commercial principles. That is whether there is a possibility of exclusive rights such as the age-old 'miners right' as argued by M.L. Smith. ${ }^{12}$

To begin with it must be noted that the common heritage principle is fast becoming part of customary international law. It constitutes a distinct basic principle providing general but not specific legal obligations with respect to the utilisation of areas beyond national jurisdiction. It inherently conflicts with the principle of sovereignty since it operates from the basis of regarding an environment as 'international public utility' requiring the obligation to co-operate. ${ }^{13}$ The $\mathrm{CHM}$ principle was first introduced to cover outer space by the words contained in Article 1 of the Declaration of Legal Principles Governing the Activities of States in the Exploration and Use of Outer Space of $1962 .^{14}$

By the time the Treaty on Principles Governing the Activities of States in the Exploration and Use of Outer Space, including the Moon and Other Celestial Borders $(1967)^{15}$ was drafted the resolve of states to render outer space a commons for all humanity had deepened. This led to the formulation of another interesting phraseology. In the discussion of the drafting of Article 1 of the Space Treaty (1967) the choice was between the terms 'province of mankind' and 'common heritage'. Eventually the former phraseology was adopted because it was thought to reflect more closely the principles of the freedom of outer space and the prohibition of appropriation. However, it must be said that introduction of the newer phrase ought not to lead to any confusion nor does this prove that these phraseologies are mere declarations of intention as some writers have mischievously suggested.

Eventually, clear reference to this term was rendered in Article 11 (1) of the Agreement Governing the Activities of States on the Moon and other Celestial Bodies (1979). ${ }^{16}$ It provided that: "The moon and its natural resources are the common heritage of mankind". In addition to this, Article 4 (1) of the Moon Agreement combines the two terms in the following manner:

"The exploration and use of the moon shall be the province of all mankind and shall be carried out for the benefit and in the interests of all countries irrespective of their degree of economic or scientific development".

\footnotetext{
${ }^{12}$ See M.L. Smith, 'The Commercial Exploitation of Mineral Resources in Outer Space', Space Law View of the Future, (Deventer, Kluwer Law and Taxation Publishers, 1988) pp. 49-55.

${ }^{13}$ See Wolfrum, op. cit., p.68; see also Said Mahmoudi, The Law of Deep Sea -Bed Mining, (Stockholm: Almkvist \& Wiksell International, 1987) et. seq.

${ }^{14}$ It states: "The exploration and use of outer space shall be carried on for the benefit and in the interests of all mankind'. UNGA Resolution 1962 (XVIII).

${ }^{15}$ Also known as the Space Treaty. 10 UKTS (1968), 18 UST 2410, 610, U.N.T.S. 205.

${ }^{16}$ Also known as the Moon Agreement. G.A. Res. 34/68, U.N. GAOR, 34th Sess. Supp. No. 46 at 77, U.N. Doc. A/34/664 (1979). Most writers insist on a legalistic interpretation of these provisions and have concluded that the Common Heritage and Province of Mankind principles are two different and distinct legal principles and cannot be used interchangeably. This certainly was the opinion of B. Maiorsky who was the negotiator of the Outer Space Treaty for the Soviet Union. See B. Maiorsky 'A Few Reflections on the Meaning and the Interrelation of 'Province of All Mankind' and 'Common Heritage of Mankind' Notions' in Proceedings of the $29^{\text {th }}$ Colloquium on the Law of Outer Space, (1986) pp. 58-61.
} 
It would, therefore, appear that as used in the Moon Agreement (1979) both terms emphasise different things although they are geared towards achieving the same noble objective. Article 4 (1) emphasises the co-operation of states parties in all their undertakings concerning the moon and other celestial bodies; on the other hand Article 11 coupled with Article 5 in particular provide the CHM Principle with legal teeth. ${ }^{17}$

\section{OUTER SPACE_RES NULLIUS OR RES EXTRA COMMERCIUM?}

In order to understand the legal status of outer space, it is considered important to determine as much as possible, which of the Latin legal classifications relating to territory apply to it. Particularly reference is made here to the well-tested doctrines of res nullius and res extra commercium. Christol rightly points out that there may be a need to identify the characteristics of the CHM principle and to distinguish it from such other principles as res nullius, res communis and res communis humanitatis.

\footnotetext{
${ }^{17}$ Article 5 reads as follows; States Parties shall inform the Secretary-General of the United Nations as well as the public and the international scientific community, to the greatest extent feasible and practicable, of their activities concerned with the exploration and use of the moon. Information on the time, purposes, location, orbital parameters and duration shall be given in respect of each mission to the moon as soon as possible after launching, while information on the results of each mission, including scientific results shall be furnished upon completion of the mission, including scientific results, shall be furnished upon completion of the mission. In the case of a mission lasting more than sixty days, information on conduct of the mission, including any scientific results shall be given periodically at thirty days' interval. For missions lasting more than six months, only significant additions to such information need be reported thereafter. (2). If a State Party becomes aware that another State party plans to operate simultaneously in the same area of or in the same orbit around or trajectory to or around the moon, it shall promptly inform the other State of the timing of and plans for its own operations. 3. In carrying out activities under this Agreement, States Parties shall promptly inform the Secretary-General, as well as the public and the international scientific community, of any phenomena they discover in outer space, including the moon, could endanger human life or health, as well as of any indication of organic life. A question that may immediately suggest itself is -why did the US accept this? A possible answer would be that up till about two decades ago the US policy regarding outer space matters was much less concentrated on commercial aims and more in tune with the realisation that outer space matters are inherently the concern of all states and peoples of the earth. In a piece of very interesting domestic legislation on Extraterrestrial Exposure- (Title 14, Section 1211 of the Code of Federal Regulations,) wherein the US took it upon itself to establish in its space operations: (a) that it is NASA policy, responsibility and authority to guard the Earth against any harmful contamination or adverse changes in its environment resulting from personnel, spacecraft and other property returning to the Earth after landing on or coming within the atmospheric envelope of a celestial body; and (b) other security requirements, restrictions and safeguards that are necessary in the interest of national security. This law makes it mandatory for a quarantine order of indeterminate period, to be issued upon all persons who have experienced extraterrestrial exposure by touching directly or indirectly extraterrestrial matter, or by exposure to the atmosphere of celestial bodies if such person was on NASA manned and unmanned space missions which land or come within the atmospheric envelope of a celestial body and return to the Earth. Whoever willfully violates, attempts to violate, or conspires to violate any provision of regulation or orders issued there under or enters or departs from the limits of a quarantine station in disregard of the quarantine rules or regulations shall be fined not more that $\$ 5,000$ or imprisoned not more than 1 year, or both. However, in 1991 Part 1211 was removed and reserved by the NASA administrator "since is has served its purpose and is no longer in keeping with current policy”. See Fed Regulation, Title 14, Chapter V, Part 1211.104 Policy; see also Code of Federal Regulations, edition of Jan. 1, 1997, Volume14, Part1200 to end, (Cat\#AE2.106/3:14/P. 1200-end/997) Part 1211 p. 75.
} 
Indeed there are a host of other principles, which may become relevant to our analysis. $^{18}$

Though it has already been concluded in several places in this work that outer space is res extra commercium it remains relevant as ever to examine arguments to the contrary. This exercise will at once reveal the falsity of similar attacks on the settled CHM principle as well as strengthen our arguments in favour of the non-appropriation regime established for outer space.

In subtle attempts to befuddle issues, the suggestion that any of the qualifications res communis or res nullius or res extra commercium or res communnis omnium can apply at any time to outer space has been rebuffed as false by writers such as Quadri ${ }^{19}$ and later even Lachs. Lachs starts off by accepting that "it is true that some of these definitions have been accepted in other areas of international law". He, however, cleverly sought to dismiss their application to outer space and celestial bodies by stating that their application is conditioned by a reply to a basic question: "Is outer space with the celestial bodies a 'thing' -res within the meaning of the law". ${ }^{20}$ Quadri also argues that such qualifications are unwarranted because they stem from an assumption that space is a res and whichever of the adjectives tacked on lacks legal significance and is at best an indication of the preference of the author or the implications, which the term res might suggest. He thinks, "the proper procedure for approaching the question would be to study the possibility of applying the term res to space". Proceeding from this reasoning he, thus, concluded that cosmic space is not a res. $^{21}$

Such strenuously made distinctions, however, serve no useful purpose. The bold thread that runs through the space treaties is that outer space and its celestial bodies should be explored and exploited in the interest of entire mankind and no one should be allowed to appropriate any parts thereof. In that case it is more sensible to hold that at least for now outer space is res extra commercium. It is important to this conclusion that no state has made incursions into space upon the basis of acquisition of territory. In fact the contrary view has always been maintained by all states that have participated in space exploration so far. Therefore, what is clearly property of all cannot be disposed of or used by any particular state or its private citizens (corporate or natural) as private property. Furthermore once the status of res extra commercium has been conferred upon any territory it becomes irrelevant to argue for a change in the legal status of the territory in question to make it res nullius considering that it already belongs to all.

\footnotetext{
${ }^{18}$ Roman Law distinguished the following inter alia: Res communes, things owned by no one the use of which was common to all, such as the air, running water, the sea and shores of the sea; res publicae, i.e. the property of the state- highways, rivers and harbors; res universitatis, property of a city such as theatres or race courses; res sacrae, religiosae and sanctae were res nullius divini iuris-That is no one owned them neither could anyone legally acquire ownership of them; res nullius humani iuris were not owned but could be acquired by any one. Examples include abandoned property and wild beasts. See C.Q. Christol, The Modern International Law of Outer Space, (1982) op.cit. p. 318. See also Roscoe Pound, Jurisprudence, Vol. II Part 3 (Minnesota: West Publishing Co. 1959) p.150.

${ }^{19}$ Seara Vazquez, Cosmic International Law (Detroit: Wayne State Univ. Press, 1985) p. 39.

${ }^{20}$ M. Lachs, The Law of Outer Space: An Experience in Contemporary Law Making, (Netherlands: Sijthoff Leiden, 1972) p. 48.

${ }^{21}$ Op. cit., p. 39.
} 
Another fine distinction, which has been advanced by proponents of the res nullius principle is that under customary international law, resources on the moon and celestial bodies are by their very nature res nullius, therefore, appropriation is legally possible. Christol, for instance, is of the opinion that there is a difference between the spatial area of the moon including celestial bodies and their natural resources. ${ }^{22}$ To explain this unacceptable position the proponents seek to make a distinction between free space and pathways on the one hand and celestial bodies on the other. With regard to free space it is said that by its very nature and by analogy to the high seas there can be no appropriation since no sovereignty may be claimed without reference to dry land. Thus, the moon and celestial bodies were merely res nullius whereas outer space i.e. free space stricto sensu was res extra commercium and the principles of non-appropriation and free access were valid both before and after the entry into force of the Outer Space Treaty on 10 December 1967.

This view is borne out of the classical but mistaken view of the nature of outer space that lawyers have. It is wrongfully assumed that outer space is a void in which solid celestial bodies float. The easiest way to puncture Christol's argument is to admit that while of course there are geophysical differences between the moon's surface on which natural resources are presently to be found and the gases and cosmic dust which constitutes the other 'spatial territories' he refers to, however, that is the whole point of giving the widest interpretations to, the scope of operation of the CHM principle. We cannot separate the spatial territory from the surface not only because the law as it is written in the Space Treaty (1967) does not do so but because those very rarefied gases, cosmic dust and energy that constitute and fill the void that is known as outer space themselves may one day if not now constitute valuable natural resources. It is not when that day arrives that we would start to develop new laws to include further spheres within the operation of the CHM principle. Therefore, it is better to adopt the view that the CHM principle applies to the whole of outer space including the celestial bodies, as well as their surface and subsurface. ${ }^{23}$

The truth, however, is that the difference between the legal status of celestial bodies and that of free space is a mere academic abstraction in the light of the rules that have so far been treated in both the Outer Space Treaty (1967) and the Moon Agreement (1979). The question that poses itself at this stage is whether res extra commercium sufficiently explains the regime governing outer space. Other writers like S.M. Williams persuasively argue that the CHM principles goes even beyond that of res extra commercium. ${ }^{24}$ The preferable interpretation to give to this is that though res extra commercium (literally meaning something, which cannot be the object of commercial trade e.g. tombs under Roman Law) is applicable it lacks the element of pronouncing outer space as the property of all. In that case res omnium, (property belonging to all) is better. On the other hand that something belongs to all does not mean that it cannot be sold for profit, say by the agreement of the parties. Thus, if the intention is to find a terminology that reflects both characteristics as closely as possible, then we must be speaking in terms of res omnium extra communis (property of all and not subject to sale). Cheng developed this theme even further to the extent

\footnotetext{
${ }^{22}$ Christol, 1982 op. cit., p. 318.

${ }^{23}$ Christol, 1982 op. cit., p. 318.

${ }^{24}$ Sylvia Maureen Williams, 'The Law of Outer Space and Natural Resources', 36 ICLQ (1987) p. 144 et seq.
} 


\section{MJIEL Vol 2 Issue 12005}

of stating that the CHM principle is a new category to be added to the tripartite division of the world made by traditional law. ${ }^{25}$

The relevance of the two terms, ownership and possession to outer space law has been challenged and a preference for licence instead has been denoted. Again it has been stated that there is a need to jettison the term res nullius and the insufficiency of even the res extra commercium formula has been alluded to. The obvious criticism such sweeping positioning is exposed to is that it may be said that in the enthusiasm of elaborating new terminology, old and tested doctrines of law are being discarded. There is, however, an appropriate defence to this criticism. If indeed new concepts have been created in space law by states in the 20th century in response to new situations which mankind has never faced before, then there is no plausible reason to limit current thinking to older doctrines, which the drafters of the pertinent space treaties had good opportunity to refer to but chose not to and indeed creatively developed alternatives for.

\section{THE SCOPE OF APPLICATION OF THE CHM PRINCIPLE IN SPACE LAW}

At this stage it is important that the exact scope of the operation of the CHM principle is determined. The rationale for such an exercise cannot be lost to any scholar on the subject who labours to defend the existence and the legal validity of the principle along with its allied principles such as the non-appropriation rule and the absence of a property regime in space. For what will be the use of establishing these rules in space law if it can at any time be successfully argued by a dissenting state or author that a specific celestial body or area of outer space or indeed an entire galaxy is beyond the application of the principle?

It must not be assumed that it is an easy task to determine what part of outer space the existing law covers. The answer as will become apparent has significance in the determination of liability for outer space activities and jurisdiction over space stations. As has been briefly mentioned the formula employed in the drafting of the Moon Agreement (1979) does not lend itself to sufficient exactitude. Admittedly the words of Article 1 limits the provisions contained therein to celestial bodies 'within the solar system'. The implications of this unnecessary limitation include the fact that once any activity takes place outside our solar system it is outside the regime of space law, at least that enunciated in that instrument. The only real beneficiary of such a limitation will be either a rogue state which, seeks to find a part of outer space which is not covered by law over which it can exercise full sovereignty, or another intelligence apart from the human race existing outside the solar system, or both. This suggestion may not be as far fetched as it sounds if we consider the fact that just 50 years ago it was largely held as impossible that man would engage in space flight or step on the moon and that a mere one hundred years ago the first aircraft was built. Thus, only the imagination limits the possibilities of exploration beyond this solar system and the discoveries that the next 50 years might bring. This is the essence of the preference for the view that space law particularly the provisions enunciating the CHM principle, apply not only to the solar system we exist in but to the entire universe of galaxies. Probably the apparent reason for the reference to the solar system in the Moon Agreement 1979 is that as the name of the treaty suggests the principal aim is to make

\footnotetext{
${ }^{25}$ See Christol, 1982 op.cit. p. 318.
} 
legislation for the moon, which is earth's natural satellite and of which there is only one in this solar system.

Let it be assumed that the limitation contained in Article (1) of the Moon Agreement (1979) is accepted. It will be discovered that even then, the clear provisions of the Outer Space Treaty (1967) survive that limitation and still operate to cover (as it reads) "outer space, including the Moon and other celestial bodies" (Article 1). The term 'other celestial bodies' is not limited to any given solar system. The CHM and the Province of Mankind principles, thus, operate to seal forever the hopes of any space explorer to discover any spatial territory to which sovereign or private rights of ownership and control can be legally claimed.

Another way of viewing the scope of application of the CHM principle is to ask if the principle applies to all the contents of empty space. The question is does space law especially the CHM principle apply to the countless mass of meteors, rocks, rarefied gases etc. over and around the earth. The generic terms found in the space treaties (for instance, 'celestial bodies' and 'the moon') make it difficult to tell whether these terms cover all natural objects in outer space irrespective of their size, structure or flight pattern. ${ }^{26}$ It was in fact suggested once that smaller bodies should have a different status from outer space proper. ${ }^{27}$ In other words only "[ $\left.\mathrm{t}\right]$ he Sun and all planets and the moon" were not to be appropriated but "meteorites....any rock in space which can really be used and controlled" should belong to another class. ${ }^{28}$

The stance that smaller natural bodies should be subject to appropriation or regarded as terra nullius by virtue of their size is unacceptable. Such a proposition is as absurd as the corresponding theory among some air lawyers to limit sovereignty over national airspace to below dense clouds or those legal theorists that say that icebergs, which flow onto the high seas, should retain the sovereignty of the territory from whence they broke off. In the first place the space treaties, which pronounce the CHM Principle, did not establish this difference. Secondly, it is quite difficult to see how anyone could prescribe the minimum size below which an object would cease to be regarded as a celestial body. The preferred view is that which holds that in the present state of man's knowledge, there is little that can serve as a basis for any distinction between a natural or physical definition of a celestial body, on one hand and a legal definition on the other. ${ }^{29}$

For all relevant purposes, therefore, the CHM principle applies not only to all 'celestial bodies' no matter how small or large and no matter in which solar system in the infinity of space they are found but also to all that may be considered 'free space'

\footnotetext{
${ }^{26}$ M. Lachs, op. cit., p. 46.

${ }^{27}$ Ibid. A list of these proposals was recorded by C.W Jenks in his Report preliminaire Institut du droit international, pp. 109-201; cf, also M.G. Markov, 'Moon Landing and International Law', III Revista di Diritto Aereo, 1964, No 9 pp. 9 ff.

${ }^{28}$ E.L Fasan, 'Law and Peace for Celestial Bodies', in Proceedings Fifth Colloquium on the Law of Outer Space, 23-29 September 1962, pp. 8 f.'; Cocca also believes that "Planets are the only celestial bodies considered from a legal viewpoint; i.e. bodies admitting occupation if they are vacant". See A.A Cocca 'Basic Statute for the Moon and Celestial Bodies', Revista di diritto Aereo No. 6, 1963, 2nd quarter, para v. On Meteorites; cf. Mc Dougall, Laswell and Vlassic, Law and Public Order in Space, (New Haven, 1963) pp 750 ff; J. Machowski, 'The Legal Status of Meteors and Meteorites', Yearbook A.A.A., 39 (1969) pp. $101 \mathrm{ff}$.

${ }^{29}$ M. Lachs, op. cit., p. 46.
} 
including gases, particles and cosmic dust. The CHM principle, however, is not applicable at all to the airspace above national territory. As regards the airspace over territories on earth over which the CHM principle applies under another body of law such as Antarctica (the World Park concept) or the Area (in the law of the sea) it may be suggested that the legal status of the airspace above those territory cannot be different from the status of the underlying territory. ${ }^{30}$ Therefore, the airspace over the area is also the common heritage of mankind but it derives its status in being so not from space law but from the laws of the sea or Antarctic law as the case may be.

Controversial as these positions taken may seem they are rational and in consonance with the legal rule of interpretation particularly that which dictates that laws should be interpreted to give effect to the intention of the drafters and to save it rather than it be destroyed. Lastly on this issue, it must be said that to engage in arguments that seek to limit the geographical or geophysical scope of the CHM principle in outer space as a method of curtailing the potency of the doctrine is a fruitless exercise. However, to engage in the intellectual exercise of determining the legal significance of the CHM principle remains a valid enquiry and is indeed a current legal problem relevant to the current century.

\section{THE CHM PRINCIPLE AND THE ARGUMENTS FOR AND AGAINST PROPERTY RIGHTS IN SPACE}

$$
\text { No Moon, no planet shall fly a single nations flag. }{ }^{31}
$$

One of the ways in which certain writers seek to attack and undermine the regime abolishing individual property rights in space is to argue that the CHM principle if ever it has any legal value at all does not in fact operate so as to block property rights in space. This argument thus, necessitates a separate enquiry as to whether CHM principle in any way permits the operation of property over space-based resources. It remains settled law that outer space including the moon and other celestial bodies is not subject to appropriation by claim of sovereignty by means of use or occupation or by any other means. ${ }^{32}$

At this stage, however, it is worth drawing a parallel between the early stages of the development of air transport and that of outer space exploration. In both cases the uncertainties over the unfolding developments helped in different ways to avert the development of legal regimes, which are solely for the interest of one or two states. In the case of air law, the leading air powers recognised the importance of not allowing any one state to have unbridled access to the air space over other national territories.

\footnotetext{
${ }^{30}$ Note our discussions on the application of the CHM Principle and the World Park Concept in Antarctica and the High Seas below. A similar reasoning is found in the argument that the airspace over the high seas should be legally regarded as part of the common heritage of mankind. See further on this theme Nicholas Grief, Public International Law in the Airspace of the High Seas, (London, Martinus Nijhoff Publishers, 1994) pp. 9, 12-13.

${ }^{31}$ Committee on the Peaceful Uses of Outer Space, 19 March 1962 A/AC. 105/PV. 2, pp. 13-15.

${ }^{32}$ Article 1 of the Space Treaty (1967) states that the exploration and use of outer space, including the moon and other celestial bodies, shall be carried out for the benefit and in the interests of all countries, irrespective of their degree of economic or scientific development, and shall be the province of all mankind. Article 11 (1) of the Moon Agreement (1979) also provides that 'The moon and its natural resources are the common heritage of mankind'. Note also Article II Outer Space Treaty (1967) and Para. 3 Declaration of Legal Principles (1963).
} 
This was principally to contain the US, which had a clear and distinct technological advantage in the air transport industry. Thus, the theory and practice of exclusive jurisdiction over national airspace by each state was upheld. In the case of space law a similar conclusion as to the undesirability of the entrenchment of hegemonic interests within the new frontier was reached with a different prescription. Rather than grant all states equal sovereignty in outer space no sovereignty was granted at all. The ideological Cold War that was at its height around 1957 produced an effect that was akin to the effects of the First World War on the shaping of air law earlier on in the 20th century. The super powers and the leading states were not sure of the way events arising out of the space activities would turn out in the context of the prevailing cold war. They were equally not certain of the particular benefits accruable from space exploration.

Thus, though the USSR was the first state to put a man in space in 1957, explicit statements were made renouncing all claims to outer space. ${ }^{33}$ It was stated that "No human activity on the Moon or any other celestial body could be taken as justification for national appropriation." ${ }^{34}$ The US also took this position long before it put a man on the Moon. The position as stated then was "We have rejected the concept of national sovereignty in outer space. No Moon, no planet shall fly a single nation's flag". ${ }^{35}$ In the words of US President Johnson "The goals now within reach of the human race are too great to be divided as spoils, too great for the world to waste its efforts in a blind race between competitive nations". ${ }^{36}$ These noble postures along with the influence of the majority of developing states facilitated the eventual formulation of the CHM principle.

The problem is that for those states that invest heavily in Space exploratory activities the cost benefit of exploiting extensively space-based resources is quite real. ${ }^{37}$ As time goes by and with the inevitable discovery of invaluable space based resources as well as newer and cheaper methods of exploiting them, it is understandable that pressures are on the increase for the law to recognise and permit property rights and the commercialisation of outer space.

It is probably worthy of note that the US would again appear to be at the forefront in the championing of commercialisation of space resources. This is probably comparable to the history of developments in air law where the US developed and actively sponsored the 'open skies' agenda in line with its hegemonic interests. ${ }^{38}$ It is,

\footnotetext{
${ }^{33}$ See Pravda, 18 November 1959 and United Nations 22 September 1960 (Official Records), p. 48 para, 58 .

${ }^{34}$ Legal Sub-committee, 20 October 1966, A/AC. 105/C.2/SR.63.

${ }^{35}$ Supra note 24.

${ }^{36}$ See Adlai Stevensen in 1st Comm. statement on; 'International Cooperation in the Peaceful Uses of Outer Space', 2 Dec. 1963, UN Press Release No. 4323, 2 December 1963. Statement also appended to the Educational Progress of NASA, Senate Hearings on Aeronautical and Space Sciences 88th Cong. 1st Sess. 21-22 Nov. 1963. See also S. Bhatt, 'Legal Controls of the Exploration and Use of the Moon and Celestial Bodies', Vol. 8 INJIL (1968) p. 36-38; A Piradov and Y. Rybakov 'First Space Treaty', International Affairs, (Moscow: Mar 3 1967) pp. 21-26.

${ }^{37}$ Anderson K. Baca, 'Property Rights in Outer Space', Journal of Air Law and Commerce, 58 (1993) pp. 1044-1045.

${ }^{38}$ Starting in 1978 when its own internal aviation market was deregulated, the US has offered very liberal bilateral agreements to other states in furtherance of the open skies agenda. It is worthy of note that up till the present the US still aggressively promotes the principle of 'open skies'. This may, however, not be in the interest of the developing states who are not strategically placed, technologically
} 
therefore, no wonder that the United States National Commission on Space recommended that "steps necessary to undertake the development of ...extra terrestrial resources begin at once". A call was subsequently made for the establishment of pilot mining and production facilities on the Moon by the year $2007 .{ }^{39}$ Western scholars such as Kosmo also believe that "the quality of America's future social and economic welfare is inextricably intertwined with the successful commercialisation of space by American private enterprise". ${ }^{40}$ Baca pushes the argument to extreme when he insists that

"...the issue of sovereignty be reconsidered in space, as some form of sovereignty is an absolute necessity to the guarantee of the property rights required for the development of space resources". 41

Christol, also thinks that there is a distinction between the ban of Article II of the Space Treaty concerning sovereign (i.e. national), appropriation of spatial areas, and the right of legal persons to obtain property. It is also argued that the provisions of Article I, and III in particular, of the Space Treaty (1967) as well as the other Articles allowing free and equal exploration, use and exploitation of the space environment by states, must be contrasted with the rights of other legal persons to engage in such exploration, use and exploitation. ${ }^{42}$

It makes sense to consider at some length the most frequently cited justifications for the position adopted by those writers who believe that the CHM principle (if at all it has a legal value) does allow the existence of property rights in outer space. They are as follows.

(1) That the term Common heritage of mankind lacks any legal or scientific clarity and therefore, means everything and nothing at all.

(2) It is claimed that the preamble to the Outer Space Treaty (1967) in fact recognises the exploitation of outer space.

(3) That Article 1 of the Outer Space Treaty (1967) (which contains the province of mankind formula a necessary adjunct of the CHM principle) is merely 'a statement of general goals' and that the ratification of specialised treaties is necessary to create any

capable or which have failing national airlines. The airspace over national territories is becoming freer for the big players in international aviation business; whereas, the possibilities of exploitation of outer space resources is becoming more than ever the exclusive preserve of those very states that benefit most from the predominance of 'open skies'. The current European Union drive towards a common international aviation policy is calculated to reduce even further the fragmentation of both industry and market within Europe so that EU Airlines and their customers will benefit from the full potential of the EU Single Market. This would of course reduce the dominance of their major international rivals particularly American ones. See generally Wybo P. Heere, 'Problems of jurisdiction in Air and Outer Space', Annals Of Air And Space Law 72 (1999); Cf. Europa, Air transport: Why An EU drive towards a common international aviation policy?, at http://europa.eu.int/comm/transport/air/international/index_en.htm; N.A. Van Antwerp, The Single European Sky, Air And Space Law XXVII No.1 April (Feb. 2001); N.A. Van Antwerp The Single European Sky (2), Air And Space Law XXVII No.2 (April 2001).

${ }^{39}$ Baca op. cit., p. 1042.

${ }^{40}$ Quoted in C.Q. Christol, (1982) op.cit, p. 318.

${ }^{41}$ Baca op.cit. p. 1047.

${ }^{42}$ Christol op. cit., p. 318. 
specific obligations. ${ }^{43}$ In the absence of such treaties Article 1 (1) is seen to be more a moral and philosophical obligation than a legal requirement ${ }^{44}$

(4) That the general principle of non-appropriation is in effect circumscribed to a large extent by treaty provisions designed to facilitate the exploration and use of outer space. In other words, Article 1 specifically makes provision for use of outer space. Because the legal sense of the word, "use" refers to the enjoyment of property often with an advantage or profit arising therefrom, by the occupancy, utilisation or exercise of the property; therefore, some form of appropriation must be permissible in order to facilitate the use contemplated in Article 1.

(5) That since the Outer Space Treaty (1967) does allow for withdrawal, the nonappropriation principle would by the operation of the law of treaties simply not apply to any state that withdraws from it.

(6) That the Moon Agreement (1979), which introduces the CHM concept, has not been ratified by any of the space powers. Also that it has not been signed by many states. Furthermore that it is not binding upon any non-party state and the claim that it represents customary law is not credible. ${ }^{45}$

(7) That in respect of the geostationary orbit the characteristics of that flight path is not analogous to the situation on celestial bodies. Thus, while the CHM principle and non-appropriation rules may work in the former they may be unworkable with respect to a lunar base, where investments will include not only equipment but also site preparation and other modifications. It is argued that in such situations the limited possessory rights and the lack of a power to dispose the property may severely limit the value of any investment. In other words space exploration may eventually suffer from space law to the detriment of mankind.

Such arguments as raised in the seven points delineated above may appear to be formidable and are indeed quite capable of attracting scholarly sympathy but again the correct view is that they are nonetheless insufficient. The arguments certainly do not justify any legal reasoning that limits the operation of the CHM principle in outer space in such a manner as to permit national or private appropriation and to recognise extensive property rights in space. Suggestions that sovereignty be introduced into outer space through a loose interpretation of the CHM principle or in any other form whatsoever is a form of legal heresy and should be dismissed for the following reasons.

In the first place it is merely mischievous to overstate the obscurity of meaning shrouding the term CHM. Doing so is clearly an undisguised attempt to avoid the

\footnotetext{
${ }^{43}$ See N. Jasentuliyana, 'Article 1 of the Outer Space Treaty Revisited', Vol. 17 Journal of Space Law, (1989) pp. 129, 139; Baca op. cit., p. 1064.

${ }^{44}$ See 'Settlement and Sovereignty in Outer Space', U.W. Ont. L. Rev., 22 pp. 155, 157-158 (1984).

${ }^{45}$ Baca op. cit., p. 1068. The Moon Agreement entered into force on July 11, 1984 with the ratification by the required fifth state, however, the record of ratification and accession to the Moon Agreement (1979) is indeed quite poor for both developed and developing states. Indeed as at 2001 only 14 states were bound by the Moon Agreement (1979) whereas 123 states are parties to the Outer Space Treaty (1976) and it may be said that developing states particularly have not justified their interest in many of the principles they fought vehemently to have included in the treaty at the conference tables by ratifying it, or by persuading other states to accede to it. It is, however, possible to over emphasise this point because the number of parties is slowly rising and dramatic increases in the number of signatories to the instrument may be easily predicted if any threat to the common understanding states have as to the general nature of the legal regime for outer space emerges or if technological developments make the exploration of the moon easier.
} 


\section{MJIEL Vol 2 Issue 12005}

legal validity of the CHM principle. Indeed it may be said with a lot of credence that specific semantic certainty has been afforded to this term in the works of many authors. R.P. Arnold impressively achieves this when he stated as follows:

"The word heritage suggests property or interests which are reserved to a person by reason of birth, something handed down from one's ancestors or the past. In defining mankind, it is necessary to make a distinction between mankind and man. Mankind refers to the collective group, whereas man refers to individual men and women...Mankind is not yet unified under one government, therefore the collective entity of mankind is represented by the various nations of the world. Thus the exercise of rights to the common heritage of mankind appertains to nations, representing mankind, and not individuals. The use of the phrase common heritage of mankind implies or prescribes worldwide ownership... ${ }^{46}$

Furthermore, due to the fact that the primary subjects of international law are independent states, it is logical that they should decide together and as a singular community, inclusive of all, fundamental matters that concern all. This is, therefore, what is legalistically referred to as mankind. ${ }^{47}$ It has, therefore, become possible to identify some basic elements of the CHM principle:

(a) That the areas constituting a CHM cannot be subject to appropriation.

(b) That the use of such area and the resources thereof shall be subject to a common management system.

(c) That the concept in question implies an active sharing of the benefits derived from the exploration and exploitation of those areas;

(d) That the area be used exclusively for peaceful purposes;

(e) That the area be preserved for future generations in perpetual succession. ${ }^{48}$

In the light of these definitions and assertions it is highly unlikely that any possible interpretation of the CHM principle allows for property rights in space. The allegation that the existing space treaties recognise exploitation of outer space through the provisions permitting space exploration is yet another unsuccessful attempt to befuddle issues. The answer to this is that there is a clear separation in space law between the issue of the use of outer space resources in outer space for scientific experimentation on the one hand and that of exploitation or mining of outer space based resources with a view to repatriating the resources to earth for economic and

\footnotetext{
${ }^{46}$ Rudolph Preston Arnold, 'The Common Heritage of Mankind as a Legal Concept', Int. Lawyer, 9 No. 1 p. 154.

${ }^{47}$ Neeru Sehgal, 'The Concept of Common Heritage of Mankind Under the Moon Agreement (1979), 1979', INJIL 26 (1986) p. 108; See also Cocca, 'Mankind as New Legal Subject - A New Juridical Dimension Recognized by the United Nations', Proceedings of the Thirteenth Colloquium on the Law of Outer Space, (1971) p. 212.

${ }^{48}$ See Williams, 'Outer Space and Natural Resources', op. cit., p. 109; Dekanozov, 'The Common Heritage of Mankind in the 1979 Agreement Governing the Activities of States on the Moon and other Celestial Bodies', Proceedings of Twenty Fourth Colloquium on the Law of Outer Space, (1981) p. 186.
} 


\section{MJIEL Vol 2 Issue 12005}

monetary gain, on the other hand. Regarding the utilisation of space based resources in outer space itself there is little room for controversy. The reasonable use doctrine has been established in Space Law. The Moon Agreement in Article 6 (2) for instance, permits the usage of minerals and other substances of the Moon in quantities appropriate for the support of their missions. This very much falls short of permitting mining for purely monetary gains. Furthermore as will be later elaborated upon, the right to collect and remove substances and minerals from the moon is limited to "... scientific investigations and in furtherance of the provisions of the agreement" (Article 6 (2) Moon Agreement 1979). The phrase "in furtherance of the provisions of this agreement" covers many things. This includes of course the obligation to have due regard to interests of present and future generations as well as the need to promote higher standards of living and conditions of economic and social progress and development in accordance with the Charter of the United Nations (Article 4, Moon Agreement (1979).

It might indeed be wondered whether the promotion of higher standards of living and economic progress would not be better served if those countries that can afford it were allowed to reap the benefits of their exploration by the granting of substantial mining rights in space law. The answer to this simply is that if that were what was intended, then the space treaties would have expressly stated so. However, what can be found in the treaties particularly within the instruments dictating the CHM principle is an intention not only to maintain outer space and its celestial bodies as common property until an exploitative regime is set up, but an obligation to share very generously benefits derived from scientific knowledge about outer space between all states irrespective of their degree of economic or scientific development (Article 4 (1) Moon Agreement (1979)). This obligation is central to the workings of the CHM/ Province of Mankind principles in space law so much so that states are advised to have regard to the desirability of making a portion of such samples available to other interested states Parties and the international scientific community for scientific investigation (Article 6 (2) Moon Agreement (1979)).

It is, therefore, inevitable to conclude that states are free to determine all aspects of their participation in the exploration and use of outer space. However, for the CHM principle to operate effectively, all states particularly those with relevant space capabilities should contribute to the promoting and fostering of international cooperation. This dictates an abandonment of property claims in outer space as well as the channelling of benefits of space exploration towards the interests of developing countries and countries with incipient space programmes (Declaration 2 and 3, Declaration on International Co-operation (1996).

As to the allegation that the CHM principle does not bind a withdrawing state from the treaties that incorporate it and that it also does not bind any of the Space powers, which does not ratify the Moon Agreement (1979), it must be said that these submissions again are based on an insufficient premise. In any event more and more states have ratified the Moon Agreement (1979) including at least one of the space powers. Furthermore, the regime of equal access to outer space created in the treaties has become part of customary international law. Therefore, a withdrawing party cannot legally gain ownership over what in effect belongs to all. Just as a party to the Chicago Convention (1944) cannot by withdrawing from that treaty unsettle the 
principle of exclusive sovereignty and jurisdiction of states in their airspace; so also cannot any state(s) undermine the status of outer space as the common heritage of mankind by inopportune withdrawal from treaty law or opportunistic approach to treaty ratification and accession.

\section{JURISPRUDENTIAL BASIS FOR COMMON OWNERSHIP, POSSESSION \& CONTROL OVER OUTER SPACE}

There are certain contradictions in the argument of those writers who expound the legality of unbridled private exploitation of resources on celestial bodies, which must be dispelled. Christol for instance, admits that, "being unable to possess sovereignty, a State may not create exclusive property rights". ${ }^{49}$ Yet he goes on to conclude as follows:

However, those public entities or those private institutions that have the capacity to engage in exploitative activities are fully competent to do so. They are as required by Article VI of the Principles Treaty, to conform to the "authorization and continuing supervision by the appropriate State Party to the Treaty." As a result of this provision it is clear that parties may exercise important jurisdictional controls. Most importantly, the distinction between national sovereignty, and the right of a State to engage in jurisdictional authority, has been recognised. The extent of such jurisdictional authority will depend upon whether a State is bound by either or both of the 1967 Principles and the 1979 Moon treaty. ${ }^{50}$

But the real issue is not whether private organisations can engage in space exploration because of course they can; however, it is clear that no state may grant exploitative or exclusive property rights to public or private entities, which go beyond that which the state itself possesses under the general principles governing space exploration in international law. In fact the authorisation and continuing supervision required of states is there in order to ensure that the conduct of space exploration and exploitation proceeds in consonance with international law. Furthermore it is important to stress that the jurisdictional duties imposed on states are not limited only to the Principles in the Outer Space Treaty (1967) and the Moon Agreement (1979) but also encompass duties that are laid down under the customary international law that has been developed in relation to outer space activities. Thus, the fact that some space faring states particularly the US, Russia, Japan and China have not ratified the Moon Agreement (1979) does not make it possible for them to totally ignore those rules of space law which are central to the regime created for the moon since they serve as evidence of contemporary international law and may in some cases arguably have become part of customary international law. ${ }^{51}$

\footnotetext{
${ }^{49}$ Carl Q. Christol, “The 1979 Moon Agreement: Where Is It Today?”, Journal of Space Law, 27 No. 1 (1999) p. 4.

${ }^{50}$ Ibid.

${ }^{51}$ China for instance has recently been reported to announce plans for a lunar station to exploit valuable resources. Again a distinction may be made between exploitation of infinite resources and those that involve finite mineral resources. The former is typified by the ambition of the Chinese to collect
} 
The effect of both the res communis principle adopted in 1967 Space Treaty and the CHM principle adopted in the 1979 Moon Agreement (1979), is to produce a prohibition against the grant of exclusive right to private property. The argument that the res communis principle, which prevents a nation from exercising sovereignty on the high seas, but allows their fishermen to exploit fisheries and gives them proprietary rights, also applies to the natural resources in outer space is only correct in the sense that that will be the course the development of the law will have to take once commercial exploitation of outer space resources begins. Moreover, there are important distinctions. Firstly, the practice of exploitation of the high seas for commercial fisheries has been going on for centuries and there is a settled recognition of that fact, prior to the development of treaties regulating the high seas in the last century, whereas the exploitation of outer space resources has hardly begun and the rules contained in the pertinent space treaties are largely in favour of sharing the benefits of exploitation between all states. Secondly as recognised by the United States delegate to the General Assembly conference adopting the Moon Agreement in 1979, even though the Agreement did not specifically put in place a moratorium on the exploitation of natural resources, any such exploitation must be carried out in accordance with Article 11, paragraph 7, and Article 6, paragraph 2. ${ }^{52}$

Article 6 (2) deals principally with the removal of samples for scientific studies. Article 11, paragraph 5 envisages that states parties to the Moon Agreement (1979) will establish an international regime to govern the exploitation of natural resources on the moon and Article 11 (7) provides that the main purposes of the regime shall include: (a) the orderly and safe development of the natural resources of the moon; (b) the rational management of those resources; (c) the expansion of opportunities in the use of those resources; (d) an equitable sharing by all states Parties in the benefits derived from those resources, whereby the interests and needs of the developing countries, as well as the efforts of those countries which have contributed either directly or indirectly to the exploration of the moon, shall be given special consideration. In any case Article 11 (8) very importantly stipulates that all the activities with respect to the natural resources of the moon shall be carried out in a manner compatible with the purposes specified in paragraph 7 .

A possible argument that may be presented is that if commercial exploitation can only take place in accordance with Article 11 (7) and that paragraph simply explains what is to be achieved by the envisaged international regime for the exploitation of natural resources on the moon as demanded by Article 11 (5) then commercial exploitation may only begin after that international regime has been put in place.

Even the Outer Space Treaty (1967), which is considered user friendly by the proponents of the theory that exploitation for commercial benefits is currently permitted, expressly stipulates in Article II that,

sunlight in orbiting stations and beam either direct light or microwave energy down to earth-based collecting points. See John Gittings and Tim Radford "The Moon -a Giant Leap for the Chinese who Spy a Business Opportunity in Space", The Guardian, Tuesday 21 May 2002, p. 3.

${ }^{52}$ UN Doc. A/SPC/34/19, 6, 7 November 1979. Note particularly Article 11 (8) which stipulates; All the activities with respect to the natural resources of the moon shall be carried out in a manner compatible with the purposes specified in paragraph 7 of this article and the provisions of article 6 , paragraph 2, of this Agreement. 
"Outer space, including the moon and other celestial bodies, is not subject to national appropriation by claim of sovereignty, by means of use or occupation, or by any other means".

This means that the drafters acknowledge that appropriation may arise by 'use'. Therefore, it may be argued that it is not possible even under this treaty, ${ }^{53}$ for any state to exploit resources on the moon for commercial benefits without at least by implication 'appropriating' it.

The requirement in Article IX that a state which is about to conduct an activity which may potentially cause harmful interference with activities of other states parties should undertake appropriate consultation before proceeding with such activity also supports the argument that any state that wants to introduce commercial exploitation must first of all embark upon international consultations. In order words such a state even if not a party to the Moon Agreement (1979) must consult with the parties to that treaty as well as the parties to the Outer Space Treaty (1967) before commercial exploitation begins. In any case one of the most likely candidates for such a move in the near future the United States has already committed itself upon the conclusion of the Moon Agreement (1979) to future participation in negotiations respecting the establishment of an international regime for governing the exploitation of the moon's natural resources. ${ }^{54}$

There is no doubt that the wish of the space faring states is to be able to carry out extensive commercial exploitation of available resources on the moon and eventually on other celestial bodies. This reality also informs the arguments of many writers on the subject. However, it may be said that pretending that the present laws allow unbridled commercial exploitation based upon property rights is not the way to go about it because they clearly do not. The problem is also not with the Moon Agreement (1979) as many writers have sought to argue. ${ }^{55}$ The real issue is that further consultations and international negotiations are still required before large-scale exploitation of the moon's resources may begin. This has been envisaged by both treaties that have been considered and cannot be ignored by any state which wants to embark on space mineral exploitation. This is also a reality that must be coped with by both statesmen and writers who advocate the concept of space 'real property rights' ${ }^{56}$ It is, therefore, possible to question the objectivity of views such as those of Professor Bin Cheng when he stated that the Outer Space Treaty (1967),

\footnotetext{
${ }^{53}$ To which very importantly the space faring states that have expressed the wish to embark on commercial exploitation (mainly the US, China and Japan) are parties.

${ }^{54}$ A representative of the US also stated that the US "would, when and if negotiations for such a regime were called for under articles 11 and 18, make a good faith effort to ensure that they are successfully concluded". UN Doc. A/SPC/34/19, 6, 7 November 1979.

${ }^{55}$ See for example Christol op.cit., p. 4. Real danger lies particularly in such views expressed by writers like Kosmo who believes that "the quality of America's future social and economic welfare is inextricably intertwined with the successful commercialisation of space by American private enterprise". Quoted in C.Q. Christol, (1982) op. cit. p. 318. Cf. A.K. Baca's view that "...the issue of sovereignty be reconsidered in space, as some form of sovereignty is an absolute necessity to the guarantee of the property rights required for the development of space resources". See Baca op. cit. pp. 1044-1045.

${ }^{56}$ See W.N. White, Jr., "Real Property Rights in Space", Proceedings Colloq. L. Outer Space 40 (1998) p. 380.
} 


\section{MJIEL Vol 2 Issue 12005}

"while it precludes the space powers from appropriating territorially portions of outer space, the moon and other celestial bodies, leaves them free, notwithstanding views to the contrary, nevertheless to appropriate their resources". ${ }^{57}$ (Emphasis added).

If indeed the common heritage principle is in any way vague and imprecise then the right to real property on the moon is even more vague as no such thing is mentioned in any treaty.

The Aristotelian analysis of justice may still serve as a crucible into which we may pour the current problems of air and space law of the 20th and 21st Centuries. Thus, it is sensible to adopt the distinction between particular justice and universal justice on one hand and distributive and corrective justice on the other hand. ${ }^{58}$ While it may be taken for granted that justice has been achieved with respect to the airspace in that every state has exclusive jurisdiction in its national airspace, the enquiry remains particularly relevant and of contemporary significance with respect to the regime governing control over outer space based resources. There is credibility in the jurisprudential premise that distributive justice is based on the principle that there has to be an equal distribution between equals and that corrective justice restores equality whenever this has been disturbed (for example by a wrongdoing). The relevance of these terms in relation to the ongoing debate about the legal status of outer space and its resources comes into sharper focus in the next few paragraphs.

To start with it may be necessary to recall the principle of the equality of states. Just as in the municipal setting justice connotes the legal equality of all persons so also among nations, equality of states reign supreme. One of the most opportune areas to test the doctrine of state equality and the obligation to take into consideration the interests of other states in resource management is found in relation to the special problem of the geostationary orbit. ${ }^{59}$ Note that it has been concluded that there is no basis for excluding the legal nature of that orbit from the legal nature of outer space in general at least for the purposes of application of the CHM principle. The unfortunate situation has arisen in which the geostationary orbit is being clogged up by satellites that belong to a few states. Since the geostationary orbit is a finite resource, the de facto commandeering of slots must not be allowed to impede distribution and access to it by a few active states. It is clear that the present position with respect to geostationary orbit use, whereby the orbit is occupied principally by a few countries,

\footnotetext{
${ }^{57} \mathrm{Ibid}$; It is obviously not enough for scholars to adopt the position of the proverbial ostriches that bury their necks in the sand. A lot of intellectual effort has been expended by some writers to proclaim property rights that simply are not there presently. Their position is very well captured in the opening quote to Christol's Article which interestingly attempts to dismiss the formidability of the Moon Agreement (1979) as an obstacle to the concept of space propertisation: It reads: "As I was going up the stair I met a man who wasn't there. He wasn't there again today. I wish, I wish he'd stay away." (Hughes Mearns, 1875) See Christol (1998) op. cit., p. 1.

58 See Aristotle, Nicomachean Ethics, V. trans. Rackham (Cambridge, Harvard University Press, 1968). See also R.W.M. Dias, Jurisprudence, fifth ed. (London, Butterworths, 1988) p. 65.

${ }^{59}$ For further discussion of the issues relating to the geostationary orbit see Gbenga Oduntan, Sovereignty \& Jurisdiction in the Airspace \& Outer Space: Legal Criteria for Spatial Delimitation, Ph.D. thesis submitted at the University of Kent (2002). See particularly chapter: 10.4: The Bogota Declaration View. See also the Bogota Declaration of $3^{\text {rd }}$ of December 1976; ITU Document WARCBS (1977) 81 E of 17 Jan. 1977. Text available in Journal of Space Law (1978) pp. 193-196. The parties to the declaration are Brazil, Columbia, Congo, Ecuador, Indonesia, Kenya Uganda and Zaire.
} 
accompanied by prompt replacement of spent satellites with newer satellites is unacceptable. Surely if it continues it may mean that other states may not in the future have orbital positions and related frequencies available. ${ }^{60}$

Significantly the CHM principle in at least this instance also works against the selfish instincts informing the usual positions taken by both developed and developing states. On the one hand, it renders untenable the central thesis of the Bogota Declaration (1976) in that no equatorial state can validly claim sovereignty over the orbit since it is the property of all. On the other hand in line with the corrective aspects of justice the 1985 Report of the Legal Committee on the Peaceful uses of Outer Space (UNCOPUOS) recognises that by reason of their geographical position the equatorial countries should be considered as having special rights to segments of the geostationary orbit superjacent to their territories. ${ }^{61}$ Yet there is the likelihood in this century that an equatorial state may wish to launch its own satellite or group of satellites and would be told it cannot do so by the International Telecommunications Union (ITU) because there are no available positions or frequencies for it. The ITU under its present rules may be justified in placing precedence to those states which have already launched satellites in accordance with its 'first come first served' policies. But then, it may well be argued that it would be completely inequitable to expect an equatorial state to accept such a scheme as just. By virtue of geophysical realities there can be no equality of circumstances at least in a factual sense between it and the non-equatorial states, which monopolise the orbit.

A simple way of providing for the interests of these states is to make special slots available for them now and reserve them in perpetuity even if they do not yet have the technological capabilities to exploit the geostationary orbit. This it must be emphasised does not create ownership or sovereignty over the orbit as it is recognised for the airspace. It merely creates a licence to operate geostationary satellites and recognises the importance of justly sharing the finite resource that the geostationary orbit constitutes.

This brings us back to the question of equality. Aristotle claims that justice is equality but only among equals, and inequality is just but only among the unequal. Therefore, he enjoins, that we treat equals equally and the unequal, unequally. Applying this to the regimes governing airspace and outer space, it must be said that both benefits and burdens must be shared equally among states. The benefits of the 'equal' distribution of sovereignty in the airspace include the right to exclude unwanted foreigners, goods, flying objects, the assurance of state security, aviation safety, financial gain through the use of airspace as bargaining chips, etc. The burdens may be said to include the obligation to respect the sovereignty of other states over their own airspace, the duty to observe rules such as the privileges and duties exchanged in the Five Freedoms and Privileges Agreement. ${ }^{62}$ In relation to outer space, benefits include the recognition of

\footnotetext{
${ }^{60}$ The geostationary orbit is a finite resource that can be 'clogged up' in the sense that there is in reality only a few 'parking spaces' in that orbit in which satellites can be placed along the same plane, for efficient coverage of the earth and without interfering or crashing into other satellites. What makes matters worse is that after a number of years some satellites wander off course and can very easily crash into nearby functioning satellites. See further Maurice N. Andem, International Legal Problems in the Peaceful Exploration and Use of Outer Space, (Finland, University of Lapland, 1992) p. 162.

${ }^{61}$ See A/AC.105/352 (April 11, 1985) pp.32-34; see further A/AC.105/370, pp.19-27.

${ }^{62}$ The Chicago International Air Transport Agreement 1944. BFSP 1; 171 UNTS 387; In force since 1945. 11 parties; UK not a party.
} 
equal access to outer space (i.e. both orbital flight paths and celestial bodies). An adjunct of the right of access to outer space is the right to ascend into outer space and to descend. This operates as derogation from airspace sovereignty in that the airspace of a state might be traversed for this purpose. Other benefits include the freedom to engage in scientific experimentation and exploration, the removal of samples from celestial bodies, space tourism and the establishment of space stations.

Delineating the burdens to be shared may prove to be more difficult. Presently some developing states seek an active role in different areas of space exploration. These include China, India, Brazil, Argentina, Indonesia, Pakistan, Mexico, Iran, and Nigeria. Nigeria for example, announced with fanfare in 1986 its plans to launch space based telecommunication satellites in the $1990 \mathrm{~s} .{ }^{63}$ In the early months of the year 2000, the President of the country announced that he was sorry but the scheme would have to wait, as there were more pressing priorities of development. Save the obligation to assist in the return of space objects and astronauts which exists in treaty law, most states simply do not stand the chance of bearing the smallest burden neither do they make even the minimal capital outlay towards outer space activities. In this way alone it becomes difficult not to see that following the Aristotelian analysis of justice there may be an amount of injustice in a regime that shares all benefits and burdens equally among transparently unequal states. If some states expend tremendous effort both in financial and intellectual terms in order to engage in outer space activities, it may indeed be argued that they deserve some preferential treatment in the sharing of rights and liabilities. An alternative will be to ensure that all states have an active participation in Outer Space activities, say for example by making equal contributions to a common body, which engages in Space exploration. However, it may be unjust to share such a burden among handicapped or disadvantaged states, which are patently unlikely to possess the necessary capacity to discharge them.

This brings us to the inescapable conclusion that scholars must locate the rationale/ justification for the prevailing regime of common ownership and control over outer space in something else apart from bare reference to the concept of 'equality'. Obviously the CHM principle/ province of mankind formula are based on the idea of distributive justice and as Dias correctly notes justice is a process, a complex and ever shifting balance between differing factors an aspect of which is equality. ${ }^{64}$ Therefore, the better view will be to state that the common ownership over outer space is a factor of universal justice. The prevailing principles operate on the basis of the common good of all states. Again it must be reiterated that just as it is makes for world order and peace that all states possess exclusive jurisdiction in national airspace, so also is it equally in the universal interest that all spatial territories above sovereign airspace should not belong to any state. Admittedly this is no more than a value judgment but it is one, which accords with international peace and harmony as well as the general tenor of the development of space law so far.

This reservation of mineral exploitation in outer space until a time in the future when an equitable regime of sharing has been established is a political and legal requirement. The right of all states to contribute to the development of this regime has

\footnotetext{
${ }^{63}$ Andem op. cit., p. 165.

${ }^{64}$ Dias op. cit., p. 66.
} 
nothing to do with the relative capacities of states to engage in scientific research. It is better to adopt the 'theory of justice'; used by John Rawls, to explain the fact that inequalities of wealth and authority are irrelevant to the imperatives of maintaining compensating benefits for everyone, and in particular for the least advantaged members of society. This is because it is undoubtedly an intuitive idea that everyone's well being depends upon a scheme of co-operation without which no one could have a satisfactory life. The division of advantages should be such as to draw forth the willing co-operation of everyone taking part in it, including if not particularly those who are less well situated. ${ }^{65}$ However, much attention must be paid to Dias' view when he wrote that;

"It is not enough to work out a just scheme of distribution, from whatever point of view but there is the further problem of getting it accepted and keeping it acceptable; which requires constant redistribution according to changing circumstances". ${ }^{66}$

It might be suggested, therefore, that rather than introduce the concepts of sovereignty or property into outer space what may be needed is a realignment of duties with respect to state participation. It may not be enough for states to send delegates to UN fora where legal and policy issues relating to outer space are deliberated upon such as the Committee for Space Research (COSPAR) and the UN Committee on the Peaceful Uses of Outer Space (COPUOS) but they may have to contribute in small ways at least to actual space research and projects. The modalities of this would have to be created under the aegis of the United Nations System.

\section{1. The Significance of Morality}

The claim by some writers that there is no room for morality in the creation of international law deserves some consideration. It is thought for instance, that moral considerations are unnecessary in space law since there have been no serious conflicts with respect to outer space. Also connected to this is the argument that the lack of a demarcation between the airspace and outer space has not generated any serious conflicts. Plausible as these arguments may sound they are not acceptable because it is very possible that serious conflicts have been avoided so far as a result of the moral content and equitable considerations inherent in the law. In other words, military and political conflicts may have been defused well ahead by the existence of those very laws which critics of the present regime claim are unnecessary. ${ }^{67}$

The assertion of Sir Harold Nicolson that "[t]here does not exist such a thing as international morality" is inapplicable to air and space law. ${ }^{68}$ The preferred view is that held by Arnold Wolfers who wrote; "the 'necessities' in international politics, and

\footnotetext{
${ }^{65}$ John Rawls, (1972) quoted in M.P.A Freeman, (ed.) Lloyd's Introduction to Jurisprudence, (London, Sweet and Maxwell Ltd., 1994) p. 466.

${ }^{66}$ Dias op. cit., p. 66.

${ }^{67}$ The relation of law to morals was one of the three subjects most debated by nineteenth -century jurists, the other two being the nature of law and the interpretation of legal history. Jhering called it the Cape Horn of jurisprudence. The juristic navigator who would overcome its perils ran no risk of fatal shipwreck. Roscoe Pound, op. cit., p. 215.

${ }^{68}$ H. Nicolson, Diplomacy, 3rd ed. (New York: Oxford University Press, 1973) p. 147. See Arnold Wolfers, Discourse and Collaboration Essays on International Politics, (Baltimore, Johns Hopkins University Press, 1973) p. 147.
} 
for that matter in all spheres of life (that states) do not push decision and action beyond the realm of moral judgment". It is an undisputable fact that considerations of morality had an influence on the development of air law. Examples of this include the universal response to the heinous crime of aerial hijack; the formulation of the aut dedere aut punire principle in air treaties and Article 3 of the Chicago Convention, which states that states must refrain from the use of weapons against civil aircraft in flight as being incompatible with elementary considerations of humanity (Declaration 4). ${ }^{69}$

Clearly this is one of the reasons why the major air and space treaties are replete with provisions that recognise the imperatives of preventing economic avarice from making an inroad into spatial territories. ${ }^{70}$ Rules of law, which permit commercial exploitation for private ends, were not advanced even though the Cold War was raging around the time the first space flight and the first moon landings took place. Indeed the United States delegate after the approval of the Moon Agreement by the COPUOS and Committee Four of the General Assembly in 1979 stated expressly that this 'balanced' and 'reasonable' agreement "would have to meet the approval of the United States Senate". ${ }^{71}$ The United States also committed itself to future participation in negotiations respecting the establishment of an international regime for governing the exploitation of the moon's natural resources. International law and politics is, therefore, rooted in ethics. States and non-state actors share a basic moral vocabulary. Therefore, if a sceptic of space law poses the question, what stops a state from acquiring outer space resources solely for its exclusive use and in an unbridled manner, the answer would be "international law forbids it". It may also be asserted that unbridled exploitation of the moon's natural resources without reference to the expectation that it is an international commons also offends international morality. Needless to say any state(s), which disregard this, attacks the rationale of its own peaceful existence. This reasoning is further reinforced by the experience of the

\footnotetext{
${ }^{69}$ Note also the Declaration Adopted by the Council of the International Civil Aviation Organisation at the Ninth Meeting of Its $156^{\text {th }}$ Session on 10 March 1999. Three main multilateral Conventions regulate jurisdiction over criminal acts against civil aviation. They are the Convention on Offences and Certain other Acts Committed on Board Aircraft of September 14, 1963 (The Tokyo Convention, 704 UNTS 219); The Convention for the Suppression of Unlawful Seizure of Aircraft of December 161970 (The Hague Convention 860 UNTS 105); and the Convention for the Suppression of Unlawful Acts against the Safety of Civil Aviation of September 23, 1971 (the Montreal Convention 10 ILM 1151). Other multilateral instruments of importance include the United Nations Convention against the Taking of Hostages of December 18, 1979 (18 ILM 1457) The United Nations Convention on the Prevention and Punishment of Crimes against Internationally Protected Persons, including Diplomatic Agents (1973) (1035 UNTS 167) and Annex 17 of the Chicago Convention 1944 which prescribes standards for aviation security. There is also the Protocol for the Suppression of Unlawful Acts of Violence at Airports Serving International Civil Aviation Supplementary to the Convention for the unlawful Acts Against The Safety of Civil Aviation (1971)(Done at Montreal on Sept. 23 1971; ICAO Doc 9518); Reprint also in XVIII-ll Annals of Air And Space Law (1993) p. 245; and the Convention On The Marking Of Explosives for the Purpose Of Detection (1991) XVIII-ll Annals of Air And Space Law (1993) p. 280. See Further Nanay Douglas Joyner, Aerial Hijacking As An International Crime (1974) p. 4; Cheng, Bin. Aviation, Criminal Jurisdiction and Terrorism: The Hague Extradition? Prosecution Formula And Attacks At Airports in Contemporary Problems Of International Law; Essays In Honour Of George Schwarzenberger On His Eightieth Birthday Cheng, Bin and E.D. Brown eds., (London, Stevens and Sons, 1988) p. 33.

${ }^{70}$ The preamble of the Chicago Convention (1944) for instance stipulates that the development of international civil aviation can greatly help to create and preserve friendship and understanding among the nations and peoples of the world, yet its abuse can become a threat to the general security.

${ }^{71}$ UN Doc. A/SPC/34/19, 6, 7 November 1979.
} 
erstwhile USSR, which was a space power and the pioneer in manned space flight. As events turned out the USSR today exists no more and Russia the main successor to its outer space programmes can hardly fund space exploration. In fact it has recently lost its last independent space station -the Mir station. Fortunately the USSR had from the beginning of its involvement with space activities acknowledged more or less that outer space is res omnium extra commercium. If this had not been so, it would have secured for itself a merely transient victory. ${ }^{72}$

It has for long been realised that much of western law, including international law, has developed in response to requirements of western business and civilisation. ${ }^{73}$ Although there is generally a conspiracy of silence over this fact it occasionally receives recognition by eminent jurists and has even been expressed by judges on the bench of the International Court of Justice. ${ }^{74}$ Any serious inquiry into this particular issue would reveal certain indications that this is a reality even in the fields of air and space law. There are indeed numerous instances in the law and practice of airspace and outer space activities, which arguably constitute evidence of bias in legal development. This does not need to be so and the directive consideration has been explained elsewhere under the theory that there is an imperative to apply the 'interest of mankind' test generally to the regulation of all international air and space activities. ${ }^{75}$ As one writer correctly puts it,

"This notion of 'general interest' is not to be taken for granted and requires to be re-defined in reference to the fast development of modern technology that mostly benefit those (a few hundred million people) who control them while others (billions of people) still creep in the back, fighting for their essentials in life". ${ }^{76}$

\footnotetext{
${ }^{72}$ Note the position taken by Soviet scholars such as Y.A. Korovin. He eloquently submitted: "of possible conception of outer space -either as 'no one's', belonging to no one (res nullius) or as an object of common use (res communis omnium) we in my opinion, should choose the second one, naturally, if the other states take the same stand." Quite prophetically, he continues; "...proceeding from the conception of outer space as an object of common use for all mankind, it is necessary to recognise that forms and methods of this "common possession" can be established only with the mutual consent of all 'users' i.e., as a result of international agreement among all the states interested in the exploration and use of outer space". Y. A. Korovin, "Conquest of Outer Space and Problems of International Relations", International Affairs, (1959), p. 90. See also A.S. Piradov (ed.), International Space Law, (Moscow, Progress Publishers, 1976) p. 86.

${ }^{73}$ O.J.Lissitzyn, "International Law in a Divided World", Int'L Conciliation (March 1963) at 37.

${ }^{74}$ Judge Amman in the Barcelona Traction Case noted that '...certain customs of wide scope became incorporated into positive law when in fact they were the work of five or six powers' Barcelona Traction (Belgium v. Spain), 1958 I.C.J Rep. 308. For wider perspectives of this issue see the following: Wade Mansell et. Al., A Critical Introduction to Law, (London: Cavendish Publishers, 1995) pp. 1-27 et passim; P. Sinha Surya, Legal Polycentricity And International Law, (1996); N'zatioula Grovogusi Siba, Sovereigns, Quasi Sovereigns and Africans: Race Self Determination In International Law, (Minnesota: University of Minnesota Press, 1996). As a writer puts it, "a major research theme that unites this diverse anti-colonial intellectual tradition is its primary focus on arguing about the limits within which the newly independent nations of Africa would embrace an international; law that was Eurocentric in its geographic origin." James Thuo Gathii, Review Essay: International Law and Eurocentricity: Introduction, 9 European Journal of International Law (1997) 184, 187.

${ }^{75}$ See Gbenga Oduntan (2003) op.cit. pp. 185- 186, 204 et passim.

${ }^{76}$ Patrick Salin, "An Overview of US Commercial Space Legislation and Policies-Present and Future", XXVII Annals Of Air And Space Law (2002) note 17, at 209-210.
} 
This is precisely why technological capability or superiority in any sector (aviation, Antarctica, deep-sea bed, or outer space) ought not to be allowed to secure hegemonic interests for any state(s) over and above the general international interest.

In essence to ask whether it is fair and moral that the moon should be free for all nations at all times is to beg the question. Naturally a scholar adopting a capitalist, hewho- dares- wins approach would advance the position that if there is gold on the moon whoever can fetch it should keep it. ${ }^{77}$ The truth, however, is that astronomically the moon is the earth's natural satellite. Any adverse changes to the moon's geophysical and environmental state will be of concern to the entire mankind. Its resources may eventually be utilised but at this stage its use must be protected and managed in the interest of both the present and future generations of mankind. Since no one is capable of laying claim to the earth then no one can own the planet's only moon or any of its parts outside the agreement of all concerned. It may indeed be immoral to seek such consent.

Another justification of the morality of the prevailing regime lies in the fact that international law particularly Article 2 (4) of the UN Charter enjoins all states to eschew wars. ${ }^{78}$ History has shown that many major wars have arisen from conflicts over territorial conquests. ${ }^{79}$ The morale, therefore, is that the moon and other celestial bodes must not become the theatre or subject of conflicts in the future. Andem is correct in noting that:

"It is logical and rational that anything common and general to all, calls for the general agreement of those concerned to formulate rules regulating its use and disposal...Any exploitation of the moon, for instance, through mining might affect the geophysical structure and composition of the atmosphere surrounding our earth, which would in turn have severe consequences not only on those states now actively engaged in the exploration and exploitation of outer space, but on all other states, developed as well as developing. ${ }^{80,}$

There is no doubt that the entire world has an interest in the development of space activities and that the CHM principle is perhaps the most significant expression of this sustaining interest. This moral and legal force behind this reasoning is well corroborated in the Latin maxim Quod omnes tangit ab omnes debet approbetur. In

\footnotetext{
${ }^{77} C f$. the views of the erstwhile President Mahithir of Malaysia. He is quoted to have said "I have heard that the South Pole is made of gold and I want my piece of it". Cited in Michael T. Kosmo, 'The Future of the Antarctic Treaty System: An Examination of the 'Common Heritage' and 'World Park' Proposals for an Alternative Antarctic Regime', Auckland University Law Review, (1992) p. 117. See also Beck, 'Antarctica at the United Nations 1988: Seeking a Bridge of Understanding', Polar Records, 25 (1989) p. 329.

${ }^{78}$ All Members shall refrain in their international relations from the threat or use of force against the territorial integrity or political independence of any state, or in any other manner inconsistent with the purposes of the United Nations. Note also the 1970 General Assembly Declaration on Principles of International laws concerning Friendly Relations and Co-operation among States U.N.G.A Resolution 2625 (XXV); note further Article 2 Moon Agreement (1979).

${ }^{79}$ Particular note must be taken of the wars and conflicts resulting from the expansion of colonial territories by the European powers.

${ }^{80}$ Andem op. cit., p. 95.
} 
other words, what affects all should be approved by all and very evidently common dangers should be the concern of all.

\section{CONCLUSIONS}

The CHM and the province of mankind terminologies are two sides of the same coin. The principles exist in the space treaties to create legal obligations, which in effect dictate co-operation among states parties in aspects of their undertakings concerning outer space, the Moon and other celestial bodies, and in the sharing of the benefits obtainable therefrom. These principles represent a relatively new category of legal classification for the explanation of jurisdiction and control over international territory. Earlier analogies can be found in the law of the sea and the legal regime governing Antarctica. For all relevant purposes the CHM principle applies not only to all 'celestial bodies' no matter how small or large and no matter in which solar system in the infinity of space they are found but also to all that may be considered 'free space' including gases, particles and cosmic dust. It does not operate over the national airspace presently.

It is probably desirable that the applicability of the CHM principle extends to the airspace over the high seas as well. This is a logical consequence of the declaration of the legal nature of the high sea-bed and ocean floor (excluding the continental shelf) and the subsoil thereof as the common heritage of mankind. Furthermore it is suggested that since the sovereignty and jurisdiction granted to states in their national airspace is delimited ratione loci in respect of the space above national territories and not ratione materiae in respect of the air, which may at any given time be filling this space. Then there is scope for the separate determination of the legal status of the air itself (i.e. the gaseous envelope surrounding the earth). In that case considering the central and irreplaceable nature of the air to the existence of human beings the sole conclusion that presents itself is that the air (ratione materiae) is best assimilated into the concept of CHM. In other words, if there is at least one thing worthy of being regarded as the common heritage of mankind the air that we breathe would certainly qualify.

Of the older classifications known to law the CHM principle is best represented by the classification of res omnium extra communis. By virtue of this the area covered belongs to entire mankind as represented by states. Sovereignty cannot in anyway be legally enforced over outer space. Until a regime of exploitation is designed for it as was done in the case of 'the Area' in the law of the sea, outer space and its resources cannot be exploited on a commercial basis. It may indeed be said that it is better that no such regime of commercial exploitation is ever developed if it would inescapably entail environmental degradation or lead to international conflicts. ${ }^{81}$

\footnotetext{
${ }^{81}$ For a treatment of "impending conflicts over the 'higher grounds' in the near future" see Oduntan (2003) op.cit., pp. 202-204. It suffice to note here that presently there is no shortage of conflicts arising from commercial usages of outer space and there should be a reluctance to create more. These include disagreements over the legality of aerial reconnaissance and remote sensing involving political/economic intelligence gathering at high altitudes and from areas coterminous with state territory (such as from the airspace above the non-sovereign maritime zones); the legality of militarization of outer space (as for instance heralded by the United States' 'Son of Star Wars') and the indeterminacy of what constitutes an aircraft or space craft in legal terms (in view of crafts with hybrid characteristics such as the X15, space shuttles and the privately owned 'spaceshipone' all adaptable for
} 
International space law presently has enshrined the CHM principle and there is no convincing reason to abandon it or limit its applicability qualitatively or quantitatively. The arguments against the legal potency of the CHM Principle are altogether insufficient to credibly cast any doubts as to the necessity and the validity of the principle in present day international law. The argument that it represents no more than a hortatory provision is unsupportable given its inclusion in the substantive parts of the Moon Agreement (1979) (Article 11 (1)). The fact that the principle also has enjoyed legal, obligatory and institutional validity in the law of the sea also proves that it was intended to and indeed has legal effect in space law.

Outer space is the most recent to be conquered in the trilogy of most important international spaces. Before the utilisation of outer space based resources can commence on a large scale or for commercial benefits, an elaborate legal regime would have to be developed. At this stage there is no such regime in place. However, as a result of the CHM principle, which applies to outer space and the celestial bodies, commercial exploitation is presently forbidden. Due to the growing restiveness of certain developed states particularly those states that also have been the keenest to exploit the deep-sea bed and Antarctica, it is imperative that all independent states should consider an exploitation regime shortly. Reasons for this include the potential for damage to the environment and the growing importance of outer space activities in the conduct of technological and scientific development. It is also important to put in place a progressive system before illegal or divergent state practice emerges in terms of space exploration and exploitation.

Before there can be any form of commercial exploitation of resources based in outer space an autonomous regime must be established under space law, with legal bodies of its own and in effective control of all activities. The Enterprise which was created for high sea-bed mining provides a good model upon which a similar organ for space exploitation may be based. The employment of "joint ventures" for outer space mining activities as is designed for the deep-sea mining is also recommended. However, unlike developments in the deep-sea regime the obligation of states Parties to finance an Enterprise mining activities must be retained. The amounts to be contributed may, however, be calculated on means related criteria. In the absence of this regime there can be no legal basis for the introduction of the concept of property or appropriation over resources based in space and on celestial bodies. It is hoped that when eventually such a progressive utilisation regime over space-based resources is put in place there would be scope for active participation in outer space activities, for all states irrespective of size and financial resources. A proportionate contribution system to the common body, which engages in Space exploitation, is desirable. It would clearly be unjust to share equally the burden among handicapped or disadvantaged states.

space tourism). Other looming problems the significance of which have been sharpened by the increasing involvement of businesses in space activities include the impending scenario of technological advancement making travel to other universes a possibility; the question of the scope of space law in view of the ambiguity introduced by the 'within the solar system' formula adopted in the Moon Agreement (1979) and not the least of course, the recurrent problem of spatial delimitation of the boundary between airspace and outer space. See further Gbenga Oduntan, "The Never Ending Dispute: Legal Theories on the Spatial Demarcation Boundary Plane between Airspace and Outer Space Vol. 1 Hertfordshire Law Journal 02 (Autumn 2003) pp. 81-84. 


\section{MJIEL Vol 2 Issue 12005}

In terms of environmental concerns it would appear that the emerging space law has a lot to learn from the development of the Antarctic regime. An example, of this is the establishment of the Committee on Environmental Protection. The equivalent of this organ would also be necessary to take control over environmental issues arising from outer space exploration and exploitation. Surely until such a body is created for outer space as well, there can be no assurance of effective policing of the international community's resolve in keeping outer space as free as possible from human contamination and harmful practices. The establishment of such a specialised body is also a sine qua non of the commencement of large-scale mineral exploitation of outer space based resources.

It is important that an invidious system of special status for certain states such as the 'consultative party' system that exist under the Antarctic system is not introduced into outer space law. All states must remain equal in all respects possible under the Space Treaties. This is to avert similar hostility to the concept of consultative parties and the hegemony they possess as found in relation to the Antarctic regime. The present system also provides the best possible checks on any potential excesses that may arise in the practice of space exploration. It suffices to repeat that the repercussions of any dangerous activity in space exploration would more likely than not be felt by all states or other states apart from the particular state that conducts the activity. It is not enough to work out a just scheme of distribution, but such a system must be achieved through compromise and negotiation. This will entail getting it accepted and keeping it acceptable. This of course requires constant redistribution according to changing circumstances.

What must be avoided at all costs is a situation whereby a few states and their commercial ventures share the commercial, technological or scientific benefits that accrue from outer space exploration and exploitation between themselves alone without reference to the envisaged regime of international cooperation and equitable sharing stipulated in the major space treaties. Furthermore it may indeed be reiterated that it is better if no commercial exploitation ever takes place on celestial bodies than for severe environmental damage to be done to the earth through the repatriation of resources from outer space. It needs also be considered if indeed human exploitation should be allowed to cause irreversible geophysical or environmental degradation to other celestial bodies all in the cause of generating economic profit for the present generation. It may also be better that a moratorium on exploitation is established to cover the better part of this century somewhat along the lines of the 50-year moratorium placed on the exploitation of Antarctica's natural resources, rather than for the world to be drawn into such international conflicts as was witnessed in the scramble by the colonialists for overseas territories, in Africa, Asia and Latin America. Lastly it must be realised that not all things that can be exploited should be exploited. The fact that technology someday makes it possible to commercially exploit the air we breathe by for instance harnessing it in some form and making it scarce for resale does not mean that the law should lend legitimisation for such an abomination.

The jurisprudential basis for common ownership, possession and control over outer space can be said to be based on the simple logic that what concerns all must be approved by all. The principles of equality of states, justice and the theory of nemo dat quod non habet apply to outer space. Therefore, the better view will be to state that the common ownership over outer space is a factor of universal justice. The use 
of all potentially finite resources must be regulated tightly under an effective international regime. Thus, resources such as the geostationary orbit need to be regulated under more effective laws, which make the de facto commandeering of slots impossible, by a few active states. It is clear that the present position with respect to geostationary orbit use, whereby the orbit is occupied principally by a few countries, accompanied by prompt replacement of spent satellites with newer satellites without any allowance for the future interests of developing states is unacceptable and may eventually culminate in friction and disputes among states. It is not difficult to predict that both the technology and ability to place satellites into geostationary orbit will become feasible to very many states within the course of this century. The ITU policy of 'first come first served' may not be adequate to cope with this eventuality and may in fact occasion indirect injustice in certain cases.

There is significant scope for the operation of the precepts of morality by states in their exploratory activities in outer space. Just as certain principles regarding the exercise of jurisdiction and control in the airspace have a moral basis so also there is a moral basis for the $\mathrm{CHM}$ and province of mankind principle in space law. International morality does forbid the appropriation of outer space for private ends either by the nation-state or by private individuals and corporate bodies. This is why technological capability or superiority in any sector (aviation, Antarctica, high seas, deep sea bed or outer space) has never been the sole necessary and sufficient reason to secure hegemonic interests over and above the general international interest. 